\title{
Electronic Business of Japan in Comparison with the U.S.
}

\author{
MYKola V. MeLnYK ${ }^{i}$, Andriy O. BLYZnYuKovii
}

With the emergence of electronic business, the Japanese incorporated the internet into their culture to take advantage of e-Commerce. The uniform language and high ratio of the urban population make the online business successful. Besides, country size and the effective infrastructure make the delivery process faster. However, Japan still needs a pace in the eCommerce business to compete with the USA. This research paper covers different trends and perspectives of Japan and the United States in terms of conducting e-Business. The article overview the primary differences between the electronic business of Japan and the United States. Then, the performance of the electronic business in both the United States and Japan is analyzed. A fine comparison has been made which determines the positive and negative impact of e-Business for both the countries. The comparison between the United States concerning e-Business helped us determine the use of modern technology, and also covers the vast dimension of online business in both countries.

The comparative analysis of the paper found that Japan needs to work on different aspects to avail opportunities of the online marketplace. The remarkable success of Japan towards online business forecast that it will take short time for Japan to take over the United States' Ebusiness. However, Japan still need to make major changes in the technical field as well as need support from the government to transform E-business in their country.

Keywords: International Business, E-commerce, Electronic business, Business Administration, Marketing in Economics, United States, e-Business in Japan.

Introduction. In the modern era, practical and innovative ways of generating more significant revenue are being proposed. One of the most efficient methods of implementing this approach is expanding the business grounds to an international level. Internet traffic is growing at an exponential rate. Therefore the most significant market from across the globe has settled down on the "Web". Companies and Enterprises have to meet the demands of not only their local customers but international as well.

The attraction of E-commerce entices and fascinates the most users to buy and support online businesses.

By definition, e-commerce is the application of communication and information technologies. It utilizes the websites for sales transactions. Most of the early developments in the electronic business are made by the United States. On the other hand, some countries are struggling to be part of it; Japan is also such a country. E-business is growing fast in Japan. Japan is the third fastest-growing e-business in the world. With a constant growth rate, the

\footnotetext{
${ }^{i}$ Mykola V. Melnyk, Doctoral Student, Kozminski University in Warsaw, Poland; Poland.

ii Andriy O. Blyznyukov, Graduate of MS Finance and Accounting Program, Kozminski University in Warsaw,

(C) M. V. Melnyk, A. O. Blyznyukov, 2021.

https://doi.org/10.21272/mer.2021.92.02
} 
Mykola V. Melnyk, Andriy O. Blyznyukov. Electronic Business of Japan in Comparison with the U.S.

Japanese e-commerce market indicates a growth of $9.1 \%$ in 2017 due to the Internet penetration in $93.3 \%$ of the Japanese population. The uniform language and high ratio of the urban population make the online business successful. Besides, retailers can deliver their products fast due to the small country size and adequate infrastructure [13].

However, the Japanese are much behind the U.S.A. in e-business. Since the beginning of the e-business, it was found that the development in the e-business depends on the customer's behavior and varies from industry to industry. Before the advent of the dot com crash, data was collected to identify the differences in Japan and the U.SA. It was observed that the ecommerce websites in the U.S.A. have advanced functionalities to process transactions as compared to Japan [14].

This research will discuss the trends and different strategic approaches adopted by two other nations successfully running their electronic businesses. The usage of the Internet in both countries is massive but there are a few differences in the way businesses are handled; each country's user approach and performance criteria vary in respect to the other. The trends followed by Japan are more conventional in relation to the ones being followed by the States.

Analysis of the cultural Difference in the electronic business of Japan and U.S.A. Analysis of e-commerce stores in the U.S.A. and Japan gives the keep insights of cultural differences in their electronic business. This section of the paper will analyze the content strategies, ecommerce strategies, and design schemes of the popular e-commerce stores in both countries.

Comparison of website categories. Since portals attract significant traffic, both Japan and Japan use web portals as sites. However, the portal types in Japan are primarily general portals, whereas specialized portals are the characteristic of the U.S. portal sites. Some examples of the U.S. portal sites are IWON.com, eUniverse network and women.com. A study reported that the second most popular sites in the U.S.A. are service sites, whereas ecommerce sites in Japan ignore the service sites. The reason can be the difference in the priorities of the residents of both countries. It can be concluded that the users in Japan don't understand the power of the Internet [14].

Recently, Japan is developing in internet technology. Most portals in Japan evolved to better service providers than the old "pasokon tsushin" services provide. Their old services providers were similar to CompuServe and Prodigy, the services providers in the pre-internet era of the U.S.A. For instance, Biglobe and @ nifty are now following the services of Microsoft crop, whereas both of them were using the service of "pasokon tsushin" offered by N.E.C. and Fujitsu, leading to a surge in the membership [3].

The Difference in layout and design. Analyzing the e-commerce pages indicated that the Japanese e-commerce sites are different from the U.S.A.'s sites in layout. The e-commerce sites in the U.S.A. have a simple form, minimalistic design, and helpful information in minimum words to provide a practical user experience. On the other hand, Japanese websites are complex, packing a variety of information in little space. Thus, Japanese websites failed to engage the consumers to stay and buy products [15].

The Difference in the payment system. Use electronic business sites mainly offer online or offline credit card payment options. A report by NetSmartAmerica.com indicates that $70 \%$ of online customers used credit cards for payment once in their online shopping time [9]. On the other hand, until 2000 "cash on delivery was the most common method to pay for the purchase. The nearest combini store can also be used as a payment/pick-up place for the buyer to receive the shipment [1].

Comparison of Performance of electronic business in Japan and U.S.A. Numbers and Ratios play an essential role in determining the performance criteria of E-business. Japan is 
the world's fastest evolving country which is revolutionizing different aspects of conducting business. However, on the other side, the United States is one of the first countries that supported the growth of online retailers. There are certain aspects of the business which prove highly favorable for Japan while others prove to be beneficial for the United States [16]. The country's massive size permits the United States to generate higher revenue and interact with people from all over the world. Still, on the contrary, Japan is not an enormous country, but the in-and-out of products is easy and convenient for the retailers and the customers.

When we take a deep look into the statistics and compare the yield of Japan and the United States in the past couple of years, we see that the United States made 71 billion dollars and Japan earned 13.5 billion dollars from online businesses [8]. The total sales accounting for Japan was 4.19 percent, and that of the United States was 6.66 percent in 2001. After this, Japan made massive transformations in its online businesses, and since then, the enterprises in Japan are working on shifting from physical stores to virtual online marketplaces.

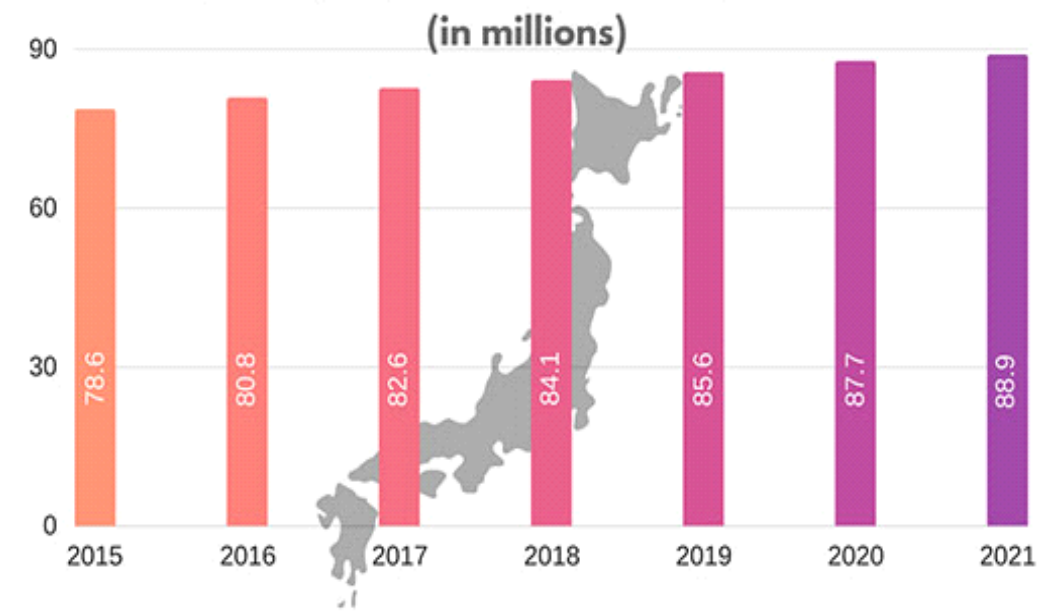

Figure 1. Increase in the number of online shoppers in Japan, million people, from 2015-2021

(Source: Statista, e-Commerce Japan)

Another reason for Japan not being able to grow its business at an exponential rate may include the hindrance in Internet usage. Many people, in the past couple of years, were not highly supportive of the excessive and intensive use of the Internet as this service charged them money vigorously [12]. But, Japan took a step towards a better and boosting economic future. The United States uses various modern features such as voice search on Amazon, subscriptions, and other ingenious ways of interacting with the public.

But, now Japan's E-Business is one of the world's most substantial and fastest online marketplaces. It has many hosts from across the globe and acquires the fourth position in commerce. However, the United States still holds the first position in this rank then comes, China and the United Kingdom. The biggest E-commerce websites in the United States are Amazon, Walmart, eBay, Target, Apple, COSTCO. While the companies which dominate the E-business in Japan are Yahoo Japan, Amazon, and Rakuten. These companies help earn more than half of the country's annual and yearly international revenue [6].

Compared with the United States, Japan has 1.2 million Online Retailers while the U.S. has 1.8 Million Online Retailers; this indicates that the United States has much advanced and 
Mykola V. Melnyk, Andriy O. Blyznyukov. Electronic Business of Japan in Comparison with the U.S.

user-friendly tools and techniques to deal with diverse consumers from all around the globe. An advantage the United States has over Japanese online stores is the use of language to communicate with various customers [7].

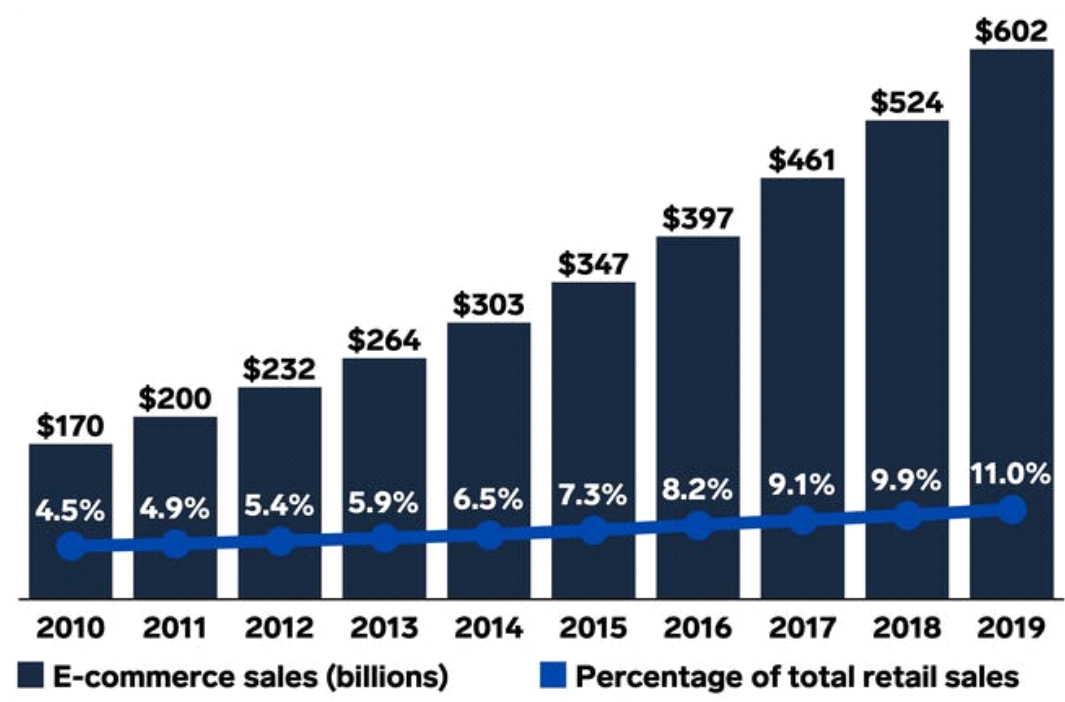

Figure 2. Surge in the online e-commerce sales in the U.S.A. from 2010-1019

(Source: U.S. Census Bureau, 2020)

The adoption of the English Language eases the selling and buying mechanism on the online website stores. The primary reason people indulge in online shopping is because of the cool features and fast delivery time online websites have to offer. Amazon is one of the biggest marketplaces in the United States, and in comparison with the most prominent Japanese retailer of Rakuten, it has hit a wider targeted audience. The brand focuses on customer delivery, suggests the products of user interest, and has expanded its market outside the home grounds. The international client number has increased on the website as compared to the domestic users.

On the other hand, Japan records the highest spike in specific months or seasons, while the States see a persistent and consistent positive response worldwide. Online clothing brands in Japan are breaking the dominance of Amazon Japan slowly and steadily. Rakuten is planning to invest in its network infrastructure, which is a positive step for the millions of users affiliated with the brand. Brands like Amazon have their payment methods, unlike many Japanese brands that offer payment through debit cards or delivery payments. Another department that needs proper care in Japan is the way revenue is sent or received.

Although Japanese retailers were skeptical and hesitant to change their modes of sales, they are also advancing with the new and better steps [8]. The E.D.I. (Electronic Data Interchange) defines the place's infrastructure from where the business is being conducted. The E.D.I. usage of the United States was the maximum in the year 2000. Still, after this period, the E.D.I. usage of the United States was surpassed by many countries, including France, Germany but Japan managed to maintain a head-to-head E.D.I. usage. This shows the rapid growth of Electronic business in Japan in comparison with the United States. 
U.S.A.'s and Japan's e-business in COVID-19. To make online shopping more accessible and to relieve the poor and young individuals, governments of different countries introduced policies to reduce the financial burden relevant to internet access [10]. The business continuity subsidy is an example of such a policy in Japan that aims at helping the firms to diversify their sales channels. Consequently, a surge in credit card usage is seen among online shoppers in Japan and the U.S.A. In Japan, around 10 million cardholders indicate an increase in online purchases. Moreover, it was found that the highest use of credit cards was among the individuals 60 years of age, increasing from $15.4 \%$ to $21.9 \%$ from January 2020 to March 2020. On the other hand, the ratio of online shopping increase to $21 \%$ among adults and to $19 \%$ among elders in the USA [11].

One of the many problems which Japan is still facing while striving for better economic growth through electronic business is the border restrictions. Also, in times of COVID-19, the state has forbidden the online supply of things. Hence, this might affect the form of online business in Japan, but on the other hand, with thousands of people stuck at home, online sales have increased a lot. According to Statista, Japan will earn approximately 100 Million Dollars through e-Commerce Sales in 2020 due to economic changes across the globe [5].

An alliance between the United States and Japan can prove very fruitful, and both countries can give a formidable challenge to China's biggest online marketplace. The Ebusiness in Japan has paved the way for local customers as well because many people do not read or write English in the country; hence, they buy from their local online stores instead of going out in the brick-and-mortar stores [4]. Many new reforms are considered, which allows the state to rebuild and strengthen its economy; online business is one of the many ways for Japan to stand on its feet once again. The way it has led so far is impressive but, at the same time, quite challenging for the United States.

Japan needs to catch up with the modern and ingenious technical trends which the United States is adapting to daily. Previously, the United States used to recommend the products to their customers only. Still, it now targets its customers' interests by checking its browsing history and recommends products accordingly. Japan still needs to catch up with this scientific technology, but the way it has made its way into the top five fastest-growing E-business countries has appalled the world [2].

Conclusion. An alliance between the United States and Japan seems to be difficult after the Cold War as it saddened and restrained their relations. Still, both countries have immense potential and can help boost the economic charts of their countries. Japan has paved its way towards online success; the chances are that it can take over the United States's E-business in a short period. Japan needs to work on a few aspects that can help open windows of opportunity for the online marketplace it has established.

However, many significant changes are still required in the technical fields, and coordination and support from the government are the most significant transforming factor. People tend to consider the e-business of the States a massive and phenomenal online marketplace because of the unique and credible features their websites have to offer. Quick delivery time and advanced technology aid such websites to target more extensive traffic. On the contrary, Japan's online sports warehouse Rakuten has attracted many United States Giants to invest in the country.

\section{References}

1. Aoki, K. (2000). Cultural differences in e-commerce: A comparison between the U.S. and Japan. First Monday.

2. Day, G. S., \& Wensley, R. (1988). Assessing advantage: a framework for diagnosing competitive superiority. Journal of Marketing, 52(2), 1-20. 
Mykola V. Melnyk, Andriy O. Blyznyukov. Electronic Business of Japan in Comparison with the U.S.

3. "Denshi nettowaaku jittaichousa kekka" [The result of the survey of the status of electronic networks in Japan] (1999). New Media Development Association in Japan.

4. Deshpande, R. Farley, J. U., \& Webster, F. (1993). Corporate Culture, Customer Orientation, and Innovativeness in Japanese Firms: A quadrad analysis. Journal of Marketing, 57, 7-23.

5. Kaplan, M. (2020). Japan Is an Enticing Market for Cross-border Ecommerce. PracticalEcommece. Retrieved from https://www.practicalecommerce.com/japan-is-a-enticing-market-for-cross-borderecommerce

6. Kushida, K. E., \& Oi, J. C. (2013) Syncretism: The politics of economic restructuring and system reform in Japan. Walter H. Shorenstein Asia-Pacific Research Center.

7. Melanie. (2018). The Current State of e-Commerce in the U.S. Unleashed Software. Retrieved from https://www.unleashedsoftware.com/blog/current-state-e-commerce-us

8. Morita, A. (1991). Japanese investment in the U.S. and US-Japan trade problems: Keynote address. Japan and the World Economy, 3(1), 113-116.

9. NetSmartAmerica.com. (2000). America.com: What makes America click. Retrieved from http://netsmartamerica.com

10. OCED. (2020). Protecting online consumers during the COVID-19 crisis. Retrieved from https://www.oecd.org/coronavirus/policy-responses/protecting-online-consumers-during-the-covid19-crisis-2ce7353c/

11. OCED. (2020). E-commerce in the time of COVID-19. Retrieved from https://www.oecd.org/coronavirus/policy-responses/e-commerce-in-the-time-of-covid-19-3a2b78e8/

12. Research and market. (2020). Japanese e-Commerce Industry Analysis 2017-2026. Retrieved from https://www.globenewswire.com/news-release/2020/07/24/2067160/0/en/Japanese-e-CommerceIndustry-Analysis-2017-2026.htm

13. SelectUSA. (2019). Japan - eCommerce. SelectUSA.

14. Vairappan, C., Cata, T., \& Sakaguchi, T. E-commerce development in Japan. Retrieved from https://www.nku.edu/ sakaguch/msis680/Vairappan06.pdf

15. WPIC. (2019). Japan e-commerce marketing trends: What are the critical differences between Japanese and Western consumers in e-commerce? Retrieved from https://www.wpic.co/blog/japan-ecommerce-marketing-trends-what-are-the-critical-differences-between-japanese-and-westernconsumers-in-e-commerce/

16. Yahagi, T., \& Kar, M. (2009). The process of international business model transfer in the SevenEleven group: US-Japan-China. Asia Pacific Business Review, 15(1), 41-58.

Manuscript received 31 March 2021

Mechanism of Economic Regulation, 2021, No 2, 16-22

ISSN 1726-8699 (print)

Електронний бізнес Японії у порівнянні з США

\section{МИКоЛА ВАЛЕРІйовИч МЕЛЬНИК, АнДРІй ОЛЕКСАНДРОВИч БЛИЗНЮКОВ **}

* аспірант, університет Леона Козмінського у Вариаві, вул. Ягелонська 57, Варшава, Польща, 03-301

тел.: +48 796181099 14, e-mail: -ds@kozminski.edu.pl

** магістрант спеціальності «Корпоративні фінанси», університет Леона Козмінського у Варшаві, вул. Ягелонська 57, Варшава, Польща, 03-301 тел.: +48 537596 736, e-mail: andriy.bly@gmail.com 
М. В. Мельник, А. О. Близнюков. Електронний бізнес Японії у порівнянні з США

3 появою електронного бізнесу японці включили Інтернет у свою культуру, щоб скористатися перевагами електронної комерції. Єдина мова та високий коефіцієнт міського населення роблять бізнес в Інтернеті успішним. Крім того, розмір країни та ефективна інфраструктура пришвидшують процес доставки. Однак Японія все ще потребує темпів у бізнесі електронної комерції, щоб конкурувати зі США. Ця стаття охоплює різні тенденції та перспективи Японії та США $з$ точки зору ведення електронного бізнесу. У статті оглянуто основні відмінності між електронним бізнесом Японії та США. Також аналізується ефективність електронного бізнесу як у США, так і в Японії. Проведено порівняння, яке визначає позитивний та негативний вплив електронного бізнесу у обох країнах.

Порівняльний аналіз статті показав, що Японії потрібно працювати над різними аспектами, щоб скористатися перевагами інтернет-ринку. Приголомшливий успіх Японії на шляху ведення бізнесу в Інтернеті прогнозує, що знадобиться короткий проміжок часу, щоб перейти на електронний бізнес у США. Однак Японії все ще потрібно зробити серйозні зміни в технічній галузі, а також заручитися підтримкою уряду для трансформації електронного бізнесу у своїй країні.

Ключові слова: міжнародний бізнес, електронна комерція, електронний бізнес, ділове адміністрування, маркетинг в економіці, США, електронний бізнес у Японії.

JEL Codes: E32, F23, L64, M16

Figures: 2; References: 16

Language of the article: English 